\title{
Effect of Thyroid Disorders on the Adult Female Albino Rats (Histological and Histochemical Study)
}

\section{Treesh SA* and Khair NS}

Department of Histology and Medical Genetics, Faculty of Medicine, Tripoli University, Tripoli, Libya

*Corresponding author: Soad Ali Treesh, Department of Histology and Medical Genetics, Faculty of Medicine, , Tripoli University, Tripoli, Libya, Tel: 00218214628052; E-mail: sotaw11@yahoo.com

Rec date: Apr 02, 2014, Acc date: Apr 28, 2014, Pub date: Apr 30, 2014

Copyright: (C) 2014 Treesh, et al. This is an open-access article distributed under the terms of the Creative Commons Attribution License, which permits unrestricted use, distribution, and reproduction in any medium, provided the original author and source are credited.

\begin{abstract}
The ovary is an endocrine and exocrine gland that plays primary role in female development and reproductive activities. The proper function of the ovary is influenced by other endocrine glands like the thyroid gland, which is one of the most important endocrine glands of the body that affects many cells all over it .This work is designed to focus on the histological and histochemical changes in adult female albino rat's ovary that happened due to thyroid gland disorders. Forty five adult female albino rats were used in this study. The rats were isolated from male rat for a month before starting the experiment then they are classified into three groups: control group, taken $0.5 \mathrm{ml}$ physiologic saline orally for three months, hypothyroid group, they were taken carbimazol at a dose of $12 \mathrm{mg} / \mathrm{kg}$ B.wt. orally for 3 months, hyperthyroid group, they were taken eltroxin at a dose of $100-u g / \mathrm{kg}$. B.wt.. Blood samples were taken for assay of serum T3 and T4. Ovaries were fixed in 10\% formol saline and paraffin sections were prepared and stained by different stains: Heamatoxylin and Eosin, Periodic acid Schiff's reaction, Methyl green pyronine and Masson 's trichrome. The result of the control rats showed the well-known histological pictures and histochemical reactions. The hypothyroid group showed an increased ovarian activity as an increase in the surface epithelial cells, excessive amount of collagen fibers, an increase in the amount of CHO materials and in DNA and RNA content. Regarding the hyperthyroid group there was degenerative changes in the ovarian follicles, decrease amount of collagen fibers and decrease in the amount of $\mathrm{CHO}$ materials in the ovarian follicles. The association between ovarian diseases and thyroid gland disorders deserves further attention as normal reproductive function needs approximately normal thyroid secretion.
\end{abstract}

Keywords: Hypothyroidism; Hyperthyroidism; Carbimazole; Eltroxin; Ovary

\section{Introduction}

Thyroid hormones are Triiodothyronine (T3) and Thyroxine (T4), which are important regulators for differentiation, growth and metabolism of virtually all tissues and organs of human body including the ovaries and endometrium [1]. The proper thyroid function is essential to have a healthy and normal reproduction [2], therefore, the female reproduction is inhibited by both hyperthyroidism and hypothyroidism [3]. The hypothyroidism is the leading cause of impaired female fertility as it causes ovulatory dysfunction [4]. Most of the women who have polycystic ovarian syndrome (PCOS) which is one of the most common endocrinopathy, in women of reproductive age, seem to be concomitantly affected by thyroid dysfunction [5].

The high prevalence of thyroid disorders that have been noticed in PCOS patients points toward the importance of early correction of hypothyroidism in the management of infertility associated with PCOS [3]. In spite of different etiology of both diseases, they have many features in common including substandard ovulation, decreased serum sex hormone-binding globulin, increased serum free testosterone, luteinizing hormone ( $\mathrm{LH}$ ) and cholesterol concentrations [6]. Some ovarian morphological changes that are typical of PCOS as the increased ovarian volume and the appearance of bilateral multicystic ovaries have been reported in various cases of primary hypothyroidism [2,7].
At the extremes of function, ovaries and thyroid gland have two types of pathological conditions. At hyper-function level, there are PCOS and hyperthyroidism affecting the ovaries and thyroid gland respectively. On the other hand, at hypo-function level, there are premature ovarian failure and hypothyroidism affecting the ovaries and the thyroid gland respectively [8] , all of these conditions are being related to infertility and leading to an abnormal pregnancy outcome, as well as they might have an underlying autoimmune etiology [9] and may be under the control of similar auto-antibodies [10]. There are some studies stated that thyroid disorders can affect the ovarian functions directly and through autoimmune pathways $[10,11]$. Other study proved that hypothyroidism is known to induce a phenotype similar to PCOS or produce features suggestive of metabolic syndrome [12]. There was an interesting observation of the inverse correlation of serum free thyroxine (FT4) quartile with various components of PCOS phenotype in chronic lymphocytic thyroiditis (CLT) in females which lends indirect support to the supposed association between PCOS and CLT [12], even in the absence of clinical manifestations of thyroid dysfunction, these diseases are rather frequent in women of reproductive age [13] and affecting 5-20\% of them [14].

Thyroid dysfunction may influence some gynecological types of cancer, but epidemiologic studies of this relationship are still limited and inconsistent [3].

\section{Aim of Study}

This study is planned to focus on the histological appearance and histochemical reactions that happened in the ovaries in cases of 
hypothyroidism and hyperthyroidism, as well as in the euthyroid conditions, also to clarify the pathological changes that can occur in the female reproductive system in association with hyperthyroidism and hypothyroidism.

\section{Materials and Methods}

Forty five adult female Albino rats, weighting 160-180 gm., were included in this study. They are housed under strict care and hygiene to keep them in normal and healthy conditions and they had access to food and water.

The rats were kept and isolated from males a month before starting the experiment. Vaginal smears were taken from the rats and stained with Hematoxylin and Eosin stain to be sure of the regularity of their estrous cycle. Three successive estrous cycles (4 days for each cycle) were required before starting the experiment [15]. The rats with the regular cycles (40 rats) were included in the experiment and the others (5 rats) who showed irregular cycles were excluded. The experimental rats were randomly divided into three groups (Table 3 ):

Group I [Euthyroid, Control group]: It is composed of 10 rats, each rat received $0.5 \mathrm{ml}$ of physiologic solution every other day orally by gastric tube for three months.

Group II [Hypothyroid group]: It is composed of 15 rats, each rat received carbimazole at a dose of $12 \mathrm{mg} / \mathrm{kg}$ dissolved in $0.5 \mathrm{ml}$ physiologic solution every other day orally by gastric tube for three months to induce hypothyroidism [16].

Group III [Hyperthyroid group]: It is composed of 15 rats, each rat received eltroxin at a dose of $100 \mu \mathrm{g} / \mathrm{kg}$ orally every other day by gastric tube for three months to induce hyperthyroidism [17].

The rats of each group were kept in separate cages till the end of the study. The rats were sacrificed by ether and laparotomy was performed. Blood samples ( $2 \mathrm{ml}$ from each rat) were taken from the heart in a plain tube and centrifuged, serum was taken to estimate levels of T3 and T4 by ELISA [enzyme linked immunosorbent assay] method .The ovaries were then dissected out, fixed in $10 \%$ formol saline then, dehydrated in ascending grades of ethyl alcohol, cleared in xylene and embedded in paraffin wax. Sections of $5 \mu \mathrm{m}$ thickness were cut by rotatory microtome and stained by the following stains: -

Hematoxylin and Eosin (H\&E) for routine histological examination, Periodic Acid Schiffs reaction (PAS) for estimation of glycogen, Masson's Trichrome technique. [M.T] for detection of collagen [18], Methyl Green Pyronine stain [MGP] for DNA and RNA [19].

\section{Results}

\section{Histological Results}

Examination of H\&E- stained sections of control rat's ovary revealed that the ovary was covered by a single layer of cuboidal epithelium (Figure 1). The epithelium was separated from the underlying ovarian tissue by a layer of collagenous fibers.

The ovarian parenchyma was formed of cortex and medulla, but there was no sharp demarcation between these two components. In the ovarian cortex, the primordial follicles were seen underneath the tunica albuginea (Figure 1).
Different forms of growing follicles were seen in the ovarian cortex, they comprised of primary and secondary follicles (Figure 2).The secondary follicle was formed of large primary oocyte in the center and surrounded by clear material (zona pellucida) and multilayers of follicular granulosa cells. The stromal cells around the follicle were differentiated into an inner vascular layer (theca interna) and an outer fibrous layer (theca externa) (Figure 1).

\begin{tabular}{|l|l|l|}
\hline Hormone estimated & Animal group & Recorded data \\
\hline T3 & Control of the laboratory & $42.2 \pm 10.3 \mathrm{ng} / \mathrm{dl}$ \\
& GI & $48 \mathrm{ng} / \mathrm{dl}$ \\
& GII & $2.19 \mathrm{ng} / \mathrm{dl}$ \\
& GIII & $73.5 \mathrm{ng} / \mathrm{dl}$ \\
\hline T4 & Control of the laboratory & $4.2 \pm 12.0 \mu \mathrm{g} / \mathrm{dl}$ \\
& GI & $5.7 \mu \mathrm{g} / \mathrm{dl}$ \\
& GII & $2.7 \mu \mathrm{g} / \mathrm{dl}$ \\
& GIII & $20.5 \mu \mathrm{g} / \mathrm{dl}$ \\
\hline
\end{tabular}

Table 1: The mean levels of the result of ELISA method for estimation of T3and T4 hormones

Tertiary follicle was larger follicle, located near the surface. It was formed of primary oocyte surrounded by clear zona pellucida and few follicular cells called corona radiata. The whole follicle was surrounded by theca interna, a secretory layer and theca externa, a fibrous layer (Figure 1 and 2). A degenerated follicle was also observed in some fields (Figure 3). The interstitial tissue was formed of groups of cells with indistinct cell boundaries and rounded nuclei (Figure 1, 2 and 3). The corpus luteum was formed of both granulosa and theca lutein cells which were polyhedral cells containing large spherical nuclei and large amount of vacuolated cytoplasm. The luteal cells were separated by spindle shaped fibroblasts and blood capillaries.

The stroma of the ovary was formed of connective tissue showing collagen fibers and blood vessels (Figure 4).

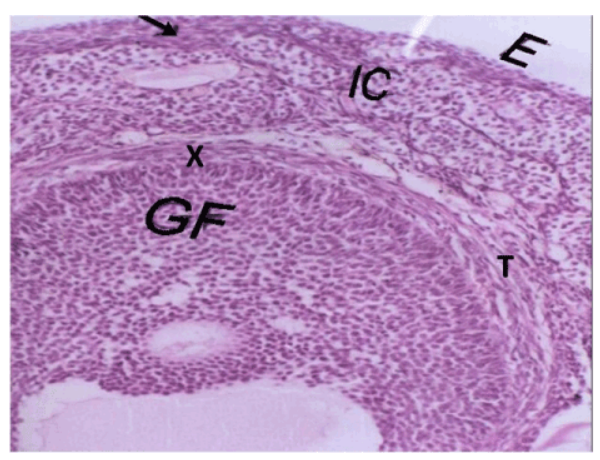

Figure1: A photomicrograph of control rat ovary showing a single layer of cuboidal surface epithelium (E), underneath it an aggregates of interstitial cells (IC) are found. Note the presence of tertiary follicle (GF).collagen fibers $(\rightarrow)$ Theca externa (X), Theca interna (T) (H\&E, X 200). 
Citation: Treesh SA and Khair NS (2014) Effect of Thyroid Disorders on the Adult Female Albino Rats (Histological and Histochemical Study) . J

Page 3 of 9

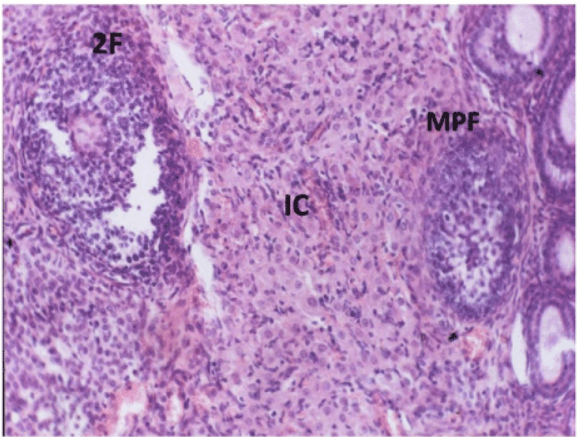

Figure2: A photomicrograph of control rat ovary denoting secondary follicle $(2 \mathrm{~F})$ at the left side. Observe a multilaminar primary follicles (MPF), and interstitial cells (IC) in between them (H\&E, X200).

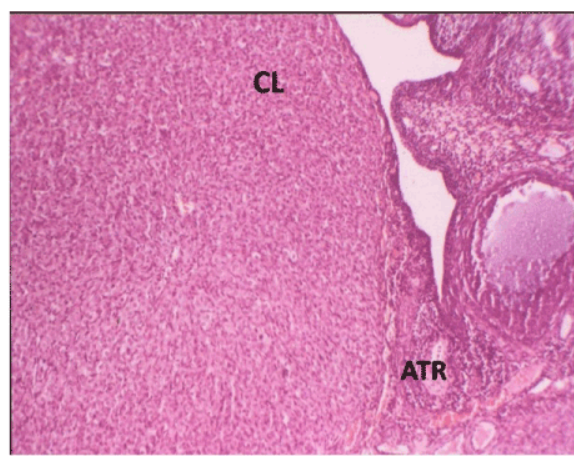

Figure 3: A photomicrographof control rat ovary depicting the corpus luteum $(\mathrm{CL})$, which is large spherical in shape. Note the beginning of atresia in secondary follicles (ATR) (H\& E, X100).

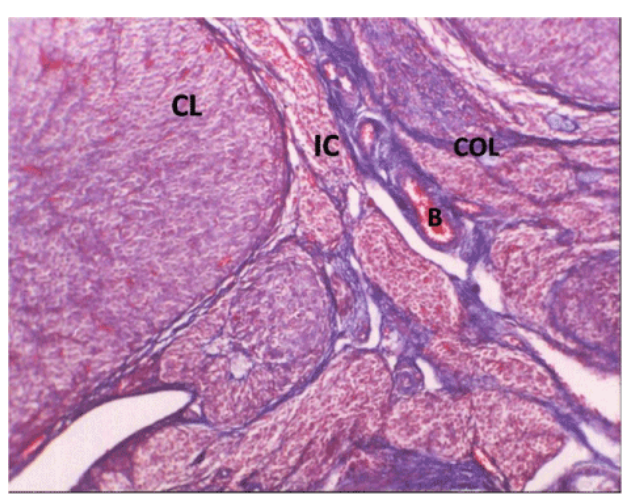

Figure 4: A photomicrograph of control rat ovary showing collagenous fibers (COL) and blood vessels (B) forming the ovarian stroma. Observe the interstitial cells (IC) among corpora lutea (CL) (M.T, X 100).
Sections of the ovary of hypothyroid rats showed the surface epithelium at different heights, some areas were covered by simple cuboidal or columnar epithelium. Proliferation of the interstitial cells among growing follicles with cystic or atretic appearance in concomitant with the increase of the thickness of tunica albuginea covering the ovary than those of the control group (Figure 5).

There was a great number of growing follicles and few numbers of primordial follicles, however numerous dilated blood vessels in interstitial tissue among atretic follicles and corpora lutea were observed (Figure 5 and 6).

The main bulk of the ovary was occupied by atretic or cystic follicles. Numerous congested capillaries were seen intermingled between the luteal cells (Figure 7).

The interstitial tissue was prominent and formed of group of cells that occupied large area under the surface epithelium and in between other ovarian components (Figure 5). Excessive accumulation of collagen fibers in the ovarian stroma were evident (Figure 7and 8).

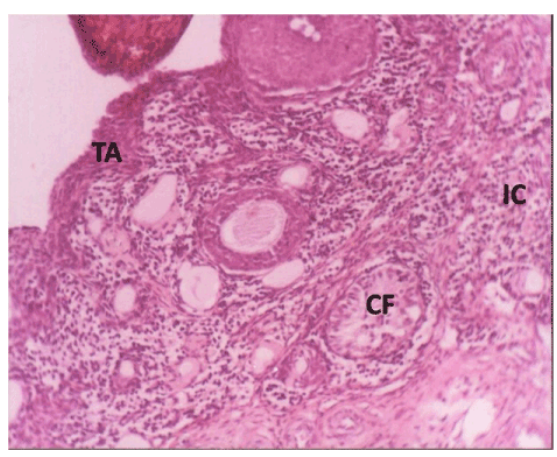

Figure 5: A photomicrograph of hypothyroid rat ovary showing invasion of the interstitial cells (IC) among growing follicles with cystic or atretic appearance ( CF) in concomitant with the increase of the thickness of tunica albuginea covering the ovary (TA) (H\& E, X 200).

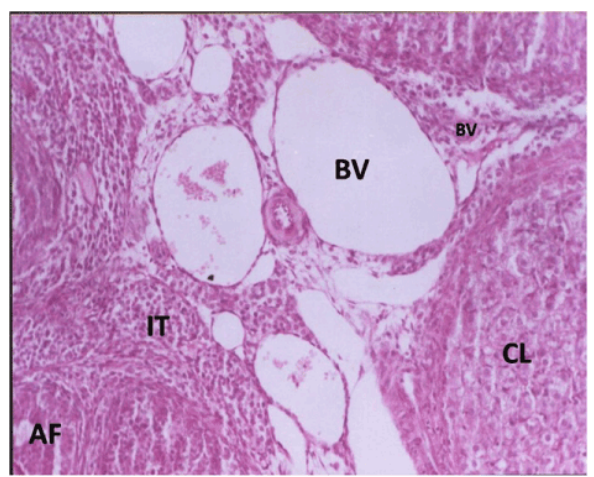

Figure 6: A photomicrograph of hypothyroid rat ovary depicting numerous dilated blood vessels (BV) in interstitial tissue (IT) among atretic follicles (AF) \& corpora lutei (CL) (H\&E, X200). 
Citation: Treesh SA and Khair NS (2014) Effect of Thyroid Disorders on the Adult Female Albino Rats (Histological and Histochemical Study) . J

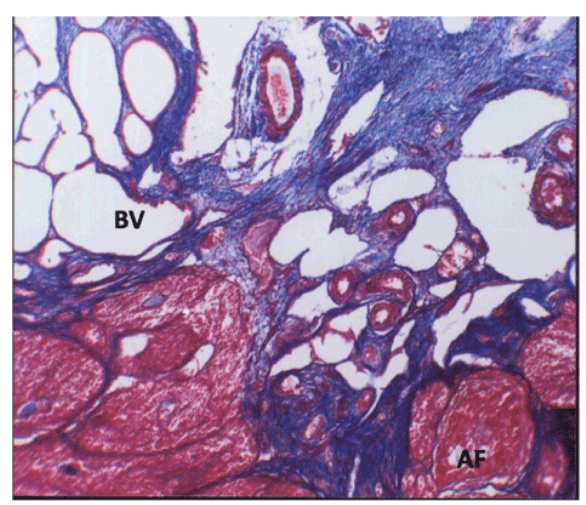

Figure 7: A photomicrograph of hypothyroid rat ovary depicting the numerous dilated blood vessels (BV) and atretic follicles (AF) (M.T, X 400).

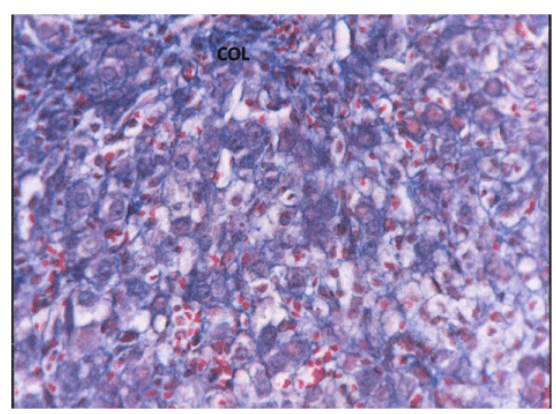

Figure 8: A photomicrograph of hypothyroid rat ovary denoting excessive accumulation of collagen fibers (COL) among extensively proliferated interstitial cells (M.T, X100).

The ovary of hyperthyroid group showed that the surface epithelium in some areas was formed of single layer of cubical cells other showed proliferated epithelium, the tunica albuginea was seen underneath the epithelium .The beginning degeneration of multilaminar primordial follicles had been occurred (Figure 9).

Most of the ovarian follicles were degenerated. The degeneration appeared in different forms; some follicles showed lysis of the primary oocyte and appearance of acidophilic material filling the cavity of follicular antrum. The surrounding granulosa cells showed pyknosis of their nuclei and degeneration of their cytoplasm (Figure 10). Other follicles were undergone atresia (Figure 12). Normal growing follicle was also seen. The most striking feature of this group was the presence of engorged blood vessels occupying the ovarian stroma in concomitant with the vacuolation of the interstitial cells (Figure 11). Traces of collagen fibers were seen in the ovarian stroma (Figure 12).

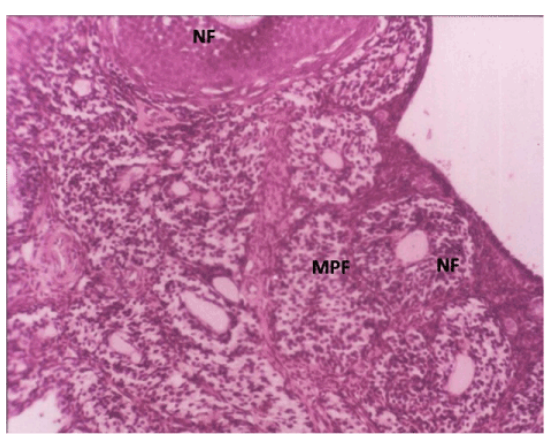

Figure 9: A photomicrograph of hyperthyroid rat ovary denoting the beginning of degeneration of multilaminar primordial follicles $(\mathrm{MPF})$ in comparison with normal follicle (NF). TA= tunica albuginea, (H\&E, X200).

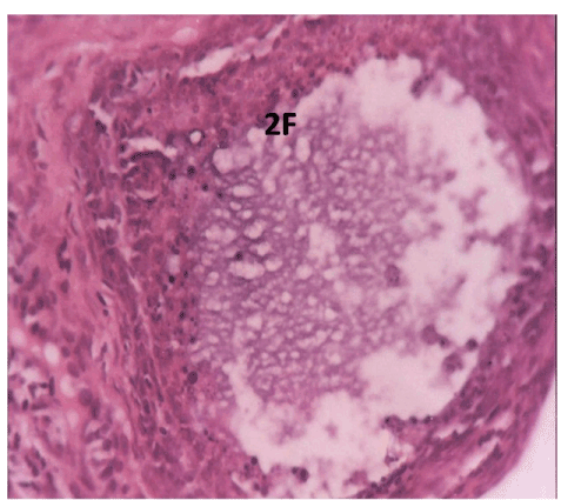

Figure 10: A photomicrograph of hyperthyroid rat ovary depicting the beginning of degenerative changes of secondary ovarian follicle (2F) (H\& E, X 400).

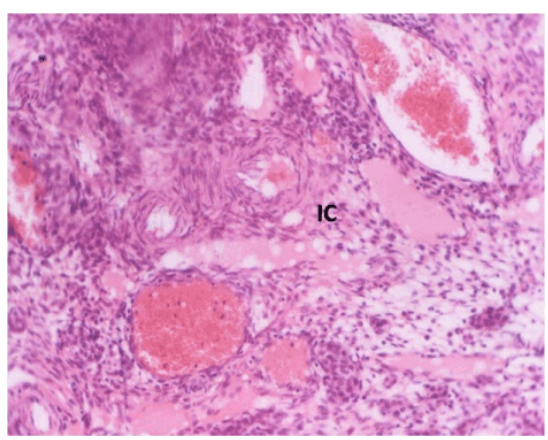

Figure 11: A photomicrograph of hyperthyroid rat ovary showing engorged blood vessels occupying the ovarian stroma. Note the vacuolation of the interstitial cells (IC) at right side (H\& E, X 200). 
Citation: Treesh SA and Khair NS (2014) Effect of Thyroid Disorders on the Adult Female Albino Rats (Histological and Histochemical Study) . J

Page 5 of 9

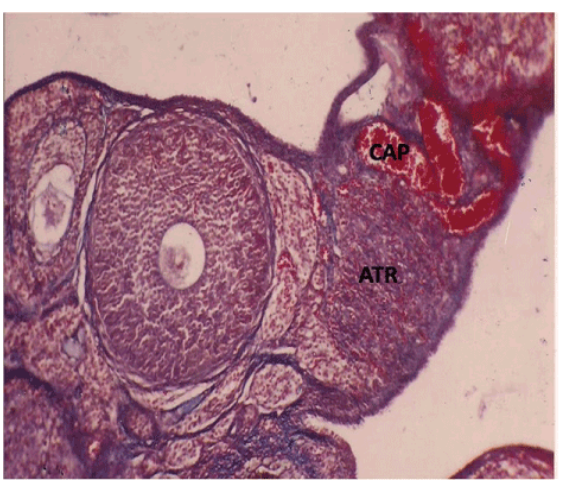

Figure 12: Section of hyperthyroid rat ovary showing numerous congested capillaries (CAP) and atretic follicles (ART) (M.T, X $100)$.

\section{Histochemical results}

\section{Periodic acid Schiff's reaction}

Control Group:

Sections of the ovary of this group revealed strong PAS reaction of the surface epithelial cells denoting their high content of carbohydrate materials. Granulosa cells of growing follicles as well as granulosa lutein cells of the corpora lutea and interstitial cells showed strong reaction for PAS (Figure 13).

\section{Hypothyroid Group:}

Sections of the ovary of this group revealed intense reaction for PAS in the surface epithelium, strong reaction in the granulosa cells of growing follicles and granulosa lutein cells of corpora lutea as well as in interstitial cells (Figure 14).

Hyperthyroid Group:

Sections of the ovary of this group showed moderate to weak reaction for PAS mostly in all ovarian components except the surface epithelium and the interstitial cells, which showed moderate reaction (Figure 15).

\section{Methyl green pyronine reaction (MGP)}

\section{Control Group:}

Sections of the control animals showed strong reaction for methyl green (bluish green color) in the granulosa cells of different ovarian follicles as well as interstitial cells (Figure 16). Strong pyronine reaction (red color) was observed in granulosa lutein cells of corpora lutea as well as in the red blood cells of the ovarian vessels (Figure 16).

\section{Hypothyroid Group:}

Sections of this group showed very intense reaction for methyl green in granulosa cells of ovarian follicles, granulosa lutein cells of corpora lutea as well as interstitial cells. Moderate pyronine reaction was detected in the cytoplasm of granulosa lutein cells (Figure 17).

\section{Hyperthyroid Group:}

Sections of this group showed moderate to weak reaction for methyl green in granulosa cells of ovarian follicles as well as corpora lutea cells. Moderate to weak reaction for pyronine was also detected in the cytoplasm of the aforementioned cells (Figure18).

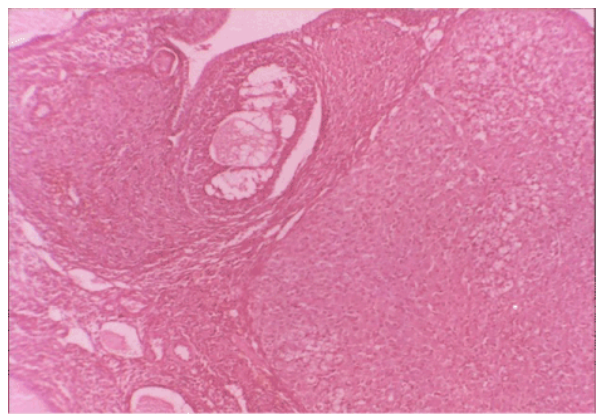

Figure 13: A photomicrograph of control rat ovary showing strong PAS reaction in surface of corpus luteum and interstitial cell (PAS, $\mathrm{X} 100)$

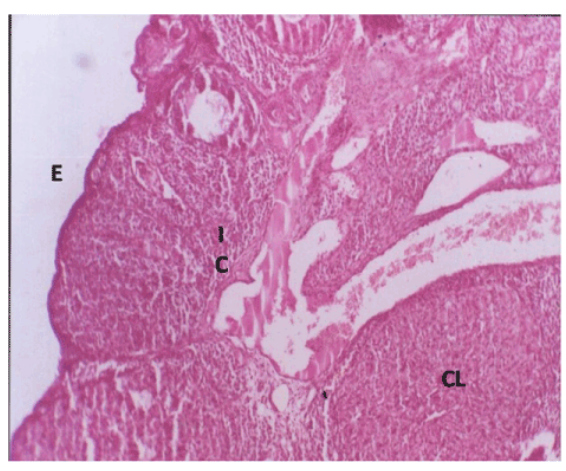

Figure14: A photomicrograph of hypothyroid rat ovary showing intense PAS +ve reaction in the surface epithelium (E) and in the interstitial cells (IC) and cells of corpus luteum (CL) (PAS ,X100).

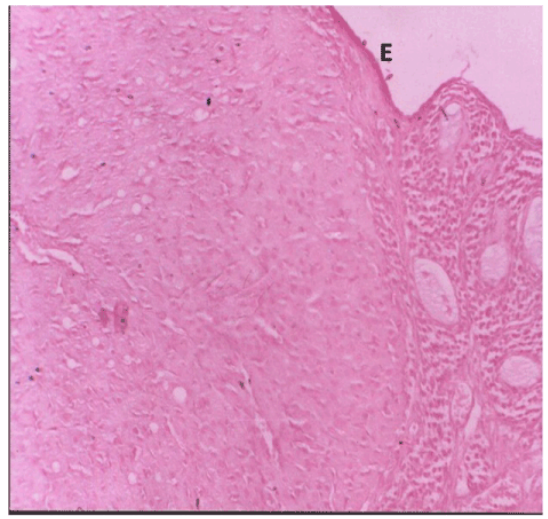

Figure 15: A photomicrograph of hyperthyroid rat ovary showing moderate reaction for PAS in granulosa lutein cells of corpus luteum. Note strong PAS reaction in the surface epithelium (E) (PAS, X 200). 
Page 6 of 9

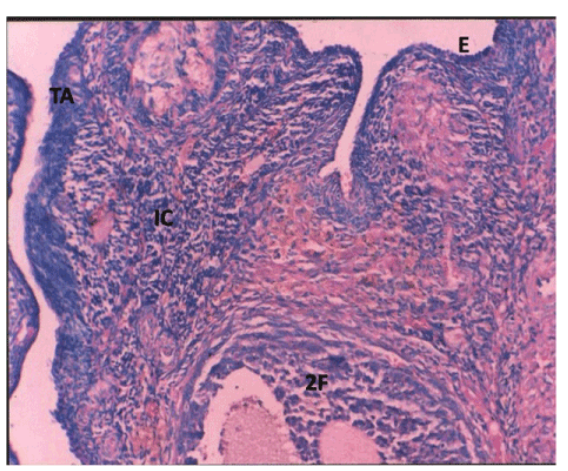

Figure 16: A photomicrograph of control rat ovary showing strong reaction for methyl green in the surface epithelium (E),tunica albuginea(TA), in the interstitial cells (IC) and granulosa cells of secondary follicle (2F) (MGP ,X 200).

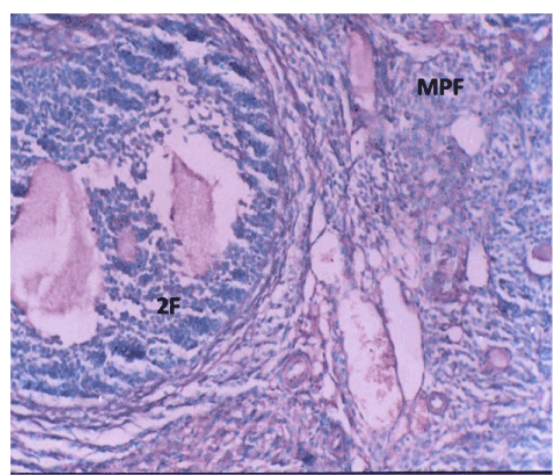

Figure 17: A photomicrograph of hypothyroid rat ovary showing intense reaction for methyl green in the nuclei of granulosa cells of antral (2nd ) follicle (2F) ,moderate degenerated multilaminar primary follicles( MPF) \& mild in interstitial cells (IC) (MGP, X 200).

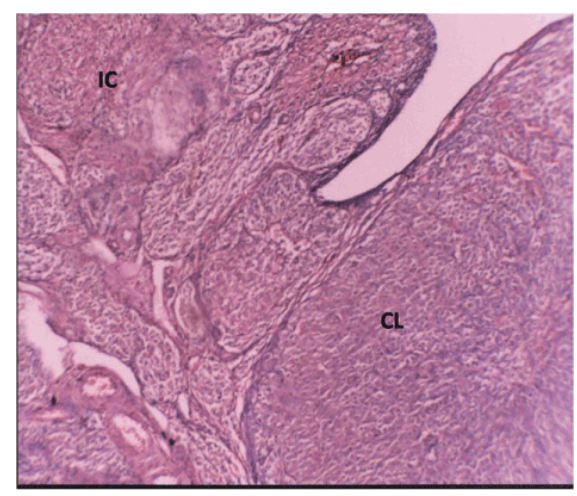

Figure 18: A photomicrograph of hyperthyroid rat ovary showing moderate reaction for pyronine in the cytoplasm of granulosa lutein cells of corpus luteum (CL) and interstitial cells (IC) (MGP, $\mathrm{X} 100)$.

\section{Discussion}

The ovary is one of the endocrine glands that plays an important role in the maintenance of the reproductive activities [20]. The thyroid gland is one of the most important glands of the body that is affecting many cells by its hormones.

Thyroid disorders can present as hyperthyroidism (excessive T3 and T4 production) or more commonly as hypothyroidism (decreased T3 and T4 production) with a higher prevalence of both disorders affecting women [21].

The correlation between the thyroid parameters and ovarian functions has been detected by many investigators $[10,17,22,23,25,26]$.

In this study, hypothyroid group injected with carbimazole showed signs of increased ovarian activity recorded in histological study of the ovary. The epithelial cells of the surface were overcrowded in some areas giving the picture of pseudostratified appearance, similar findings were observed in rats treated with bromocriptine [27], and in rats treated with carbimazole for three months [28].

Hypothyroid group also showed thick tunica albuginea and excessive amount of collagen fibers in the ovarian stroma. This was in agreement with [29] who found significant increase in the total collagen fibers, they attributed this increase to the decrease in collagen degradation by diminished lysosomal enzymes in hypothyroid rats. The striking observation detected in the present study was the appearance of cysts-like structures. Most of the ovarian follicles were degenerated that replace most of the ovarian follicles in the hypothyroid-treated group. These findings were in accordance with [30] and [22].

[31] reported that hypothyroidism is usually associated with ovarian follicular cysts and hypergonadism which are the two cardinal signs of polycystic ovary syndrome in human female. This was supported previously by [32] who clarified that estriol was formed in hypothyroid patients via 16 - hydroxylation pathway instead of normal 2 - hydroxylation. As the estriol is less potent than estradiol in feedback regulation of gonadotrophin secretion, so estriol in hypothyroid patients resulted in ovarian hyperstimulation and development of ovarian cysts. Also severe longstanding hypothyroidism leads to increased ovarian volume and/or cyst formation [2].

In the present study, the hypothyroid group, vacuolated stromal cells were detected most probably representing those of the interstitial gland. This finding was explained by the researchers [33], as stromal hyperthecosis, microscopically, it was noted as hypercellular stroma with luteinization of stromal cells that appear with a vacuolated cytoplasm [26].

On the other hand, hypothyroidism of female gerbils resulted in arrest of follicular development and atresia of most of the ovarian follicles, a condition termed as atrophic ovaries as has been previously reported by [34]. However, [35] stated that, the effect of hypothyroidism on gonads may vary with animal species, the age of the animals, the method used to induce hypothyroidism and the duration of hypothyroidism. Moreover, [36] stated that ovaries of rats treated with propylthiouracil to induce hypothyroidism showed more secondary and less antral follicles. They concluded that this disturbed folliculogenesis is due to inadequate thyroid hormone supply, which hampers the differentiation and not the proliferation of the granulosa cells. 
The interstitial cells were markedly the increased incidence of proliferation of these cells. It was supposed to be derived from the theca interna cells of the ovarian follicles that proliferate and become active steroid secretors.

Furthermore, it was also observed that corpora lutea were enlarged and showed signs of increased activity. On the other hand, [36] they have detected corpora lutei in rats treated with propylthiouracil to induce hypothyroidism and attributed this condition to the low level of thyroxine which has a role in maintenance of differentiation of follicular granulosa cells to granulosa lutein cells.

In addition, competitive binding studies with thyroid hormone analogues indicated that triiodothyronine (T3) binding to corpus luteal nuclei is hormone - specific. These findings observed in the ovarian stroma of this group. They appeared in groups surrounded by connective tissue fibers. This could indicate that, there is direct effect of thyroid hormone on the corpus luteum [37]. Concerning the histochemical reaction, glycogen is intracytoplasmic inclusion found normally in every tissue of the body mainly in the liver and muscles. It was demonstrated in the ovary of control animals in this study as well as other studies [14]. Enlargement and cystic changes in ovaries of patients with hypothyroidism has been observed in numerous case reports after raised this concern the first time [38], [39].

Dilated congested blood vessels were observed in both hypothyroid and hyperthyroid rats, this finding could be attributed to the increased vascular supply needed for the growing corpora lutea and the increase in their functional activity [26].

The present study revealed intense PAS reaction in the granulosa cells of growing follicles, granulosa lutein cells of corpora lutei and interstitial cells. This finding denoting presence of carbohydrate materials $(\mathrm{CHO})$ in the ovary of hypothyroid rats. The pattern of $\mathrm{CHO}$ distribution noticed after using synthetic estrogen (DES) was indicated by +ve reaction with PAS in both luteal and thecal cells, many clusters of alpha and beta glycogen granules by using electron microscope denoting that these cells synthesize such $\mathrm{CHO}$ materials were illustrated [40].

Methyl green pyronine reaction demonstrates two nucleic acids; deoxyribonucleic acid (DNA) which is the main nuclear component and the ribonucleic acid (RNA) which present mainly in the cytoplasm and to a lesser extent in the nucleus

In control group, DNA staining density was strong in the nuclei of the surface epithelium, granulosa cells, lutein cells as well as interstitial cells. Cytoplasmic RNA content of these cells was strong.

In hypothyroid inducted group, the intensity of the reaction for methyl green pyronine was increased. This was in agreement with [41], they interpreted the association between the hypothyroidism and ovarian hyperstimulation by their opinion that hypothyroidism synthesized the ovarian follicles to a potentiated FSH response resulting in ovarian hyperstimulation.

On the other hand, [34], reported that induction of hypothyroidism in female gerbils resulted in decrease concentration of RNA and protein the treated animals and L- thyroxine replacement therapy restored these biochemical changes.

Hyperthyroid animals group injected with eltroxin for three months resulted in degenerative changes in the ovarian follicles. These changes were in the form of lysis of the primary oocytes of the growing follicles and degeneration of the granulosa cells. Similar finding was observed by [42], who described a rise in some enzymatic activity such as alkaline phosphatase and ATPase after using some insecticides. These enzymes could reflect the degenerative changes that occurred in the ovarian follicles or it may be due to lower affinity of the ovarian follicles for metabolic degradation.

On the other hand [14], reported that, the administration of eltroxin for 2 months to mice resulted in ovarian hyperstimulation and they attributed this to the action of granulosa cells which was stimulated by eltroxin and producing excess estrogen, the main causative factor for this hyperstimulation, also the treatment with eltroxin for 3 months resulted in regressive changes and degeneration in the ovarian follicles. This controversy may result from species difference and period of treatment [14].

In our study, a minimal amount of collagen fibers were detected in the ovarian stroma, when compared with control group. These could be due to inhibitory effect of eltroxin on collagen synthesis. Similarly [29], demonstrated a decrease in collagen in hyperthyroid rats and attributed this to the increase in lysosomal enzymes, which increase the uterine and cervical collagen degradation. The most striking feature in this group is the vascular congestion of the ovarian vessels. This could be attributed to the direct load of eltroxin on the cardiovascular system, [43]. The thyrotoxicosis places a considerable load on the cardiovascular system, and the main symptoms of patients with hyperthyroidism are cardiovascular. Thyrotoxic heart disease and heart failure are common in those patients [43].

In hyperthyroid group, decrease in amount of carbohydrates was detected in ovarian follicles as observed by moderate reaction for PAS, when compared to control group, which showed strong reaction. However, the surface epithelium and the interstitial cells showed strong PAS reaction. This was in agreement with [43], who mentioned that long term thyrotoxicosis leads to glycogen depletion in the liver that makes it susceptible to injury and liver failure. Moreover, [42], described an alteration in some enzymatic activity that had led to metabolic degradation and inhibited the carbohydrate synthesis in the ovarian follicles after using some insecticides. In addition, this decrease in PAS reaction was attributed to the occurrence of regressive changes and conversion of the follicles to fibrotic masses after 3 months of eltroxin administration [14].

Methyl green pyronine reaction in hyperthyroid group was decreased in this study denoting a decrease in DNA and RNA content of follicular cells. Similarly, detected decrease in total protein, 3 months after eltroxin treatment denoting decrease in DNA and RNA content of the ovarian follicular cells [14], additionally, the ovarian total protein levels determined by biochemical assays were not significantly affected by neither administration of cadmium nor with cadmium and zinc or with zinc alone in rabbit [44]. These changes could be attributed to species difference. The presence of vacuoles in the interstitial cells in hyperthyroid d group of this study could be due to accumulation of lipid droplets and hexose -containing mucopolysaccharides on histochemical studies on atretic ovarian follicles of rats [45].

Consistent regression of the ovarian cysts after thyroid hormone replacement therapy supports a causal relationship between hypothyroidism and ovarian stimulation. In addition, the presence of ovarian cyst has been considered a diagnostic marker for hypothyroidism [46,47]. 


\section{Conclusion}

A strong interaction between thyroid and ovary is implied by many in vitro researches, both in humans and animals. It is necessary to consider hypothyrodisim and other endocrine disorders in the differential diagnosis of adult patients with ovarian multiple cyst formation in order to prevent inadvertent ovarian surgery [24]. So , it will be helpful to assess thyroid hormones routinely in patients with PCOS and offer thyroid hormone replacement therapy if necessary [10].

In brief, from the present study, hypothyroidism had led to development of ovarian cysts, atretic follicles and proliferation of interstitial cells, also we noticed that hypothyroidism was greatly associated with a delay in sexual maturation and development.

This study also showed that hyperthyroidism for a long time was capable of exerting marked changes in the configuration (degenerative changes) and in the intensity of carbohydrates and proteins of rat ovaries.

We advise that, severe longstanding hypothyroidism leads to an increase in the ovarian volume, which can also be accompanied by cyst formation. Therefore, patients with suspected PCOS (both based on clinical and hormonal profile changes) should be reevaluated after a possible underlying hypothyroidism has been appropriately treated. The association between ovarian diseases and thyroid gland disorders deserves further attention as normal reproductive function needs approximately normal thyroid secretion.

\section{Acknowledgements}

The author thanks Dr Nagiat $T$ Hwisa, Department of Pharmacology, Faculty of Pharmacy, AlZawia University, AlZawia, for her help in preparing the experimental part.

\section{References}

1. Krassas GE, Poppe K, Glinoer D (2010) Thyroid function and human reproductive health. Endocr Rev 31: 702-755.

2. Muderris II, Boztosun A, Oner G, Bayram F (2011) Effect of thyroid hormone replacement therapy on ovarian volume and androgen hormones in patients with untreated primary hypothyroidism. Ann Saudi Med 31: 145-151.

3. Kang JH, Kueck AS, Stevens R, Curhan G, De Vivo I, et al. (2013) A large cohort study of hypothyroidism and hyperthyroidism in relation to gynecologic cancers. Obstet Gynecol Int 2013: 743721.

4. Krassas GE (2000) Thyroid disease and female reproduction. Fertil Steril 74: 1063-1070.

5. Sinha U, Sinharay K, Saha S, Longkumer TA, Baul SN, et al. (2013) Thyroid disorders in polycystic ovarian syndrome subjects: A tertiary hospital based cross-sectional study from Eastern India. Indian J Endocrinol Metab 17: 304-309.

6. Blackwell RE, Chang RJ (1986) Report of the National Symposium on the Clinical Management of Prolactin-Related Reproductive Disorders. Fertil Steril 45: 607-610

7. Cardoso CG, Graça LM, Dias T, Clode N, Soares L (1999) Spontaneous ovarian hyperstimulation and primary hypothyroidism with a naturally conceived pregnancy. Obstet Gynecol 93: 809-811.

8. Ehrmann DA (2005) Polycystic ovary syndrome. N Engl J Med 352: 1223-1236.

9. Gleicher N, Barad D, Weghofer A (2007) Functional autoantibodies, a new paradigm in autoimmunity? Autoimmun Rev 7: 42-45.

10. Du D, Li X (2013) The relationship between thyroiditis and polycystic ovary syndrome: a meta-analysis. Int J Clin Exp Med 6: 880-889.
11. Unuane D, Tournaye H, Velkeniers B, Poppe K (2011) Endocrine disorders \& female infertility. Best Pract Res Clin Endocrinol Metab 25 861-873.

12. Ganie MA, Marwaha RK, Aggarwal R, Singh S (2010) High prevalence of polycystic ovary syndrome characteristics in girls with euthyroid chronic lymphocytic thyroiditis: a case-control study. Eur J Endocrinol 162: 1117-1122.

13. Moravvej A, Jeddi-Tehrani M, Moghaddam ARS, Dokouhaki $P$, Shekarabi M, et al. (2009) Assessment of Thyroglobulin Expression in Reproductive Organs at Different Stages of Mouse Estrous Cycle. Avicenna J Med Biotechnol 1: 41-46.

14. El-Banhawy WA, El-Desouki NI (1997) Effects of Eltroxin treatment on the histology and histochemistry of the ovary of BALB/C mice. Egypt J Histol 20: 187 - 207.

15. Baker HJ, Lindsey JR, Weisbroth SH (1979) The estrous cycle in the rat In: The laoboratory rat. Biology and Diseases, Academic press, Toronto, New York, London.

16. Abo Rabia NHA (1990) Study on the thymus of the albino rats at different ages and the effect of experimentally induced hypo-and hyperthyroidism on its structure. Ph.D. Thesis, faculty of medicine, Ain Shams University.

17. Bandyopadhyay A, Roy P, Bhattacharya S (1996) Thyroid hormone induces the synthesis of a putative protein in the rat granulosa cell which stimulates progesterone release. J Endocrinol 150: 309-318.

18. Kiernan JA (1999) Histological and Histochemical methods, Theory and Practice (3rd edn), Butter Worth Heinemann, Replika Press Pvt Ltd, Delhi, India.

19. Bancroft JD, Stevens A, Turner DR (1996) Theory and practice of Histological technique, Churchill, livingstone, NY.

20. Carr BR, Blackwell RE (1998) Textbook of Reproductive Medicine, Stamford, CT, Appleton \& Lange.

21. McDermott MT (2012) Hyperthyroidism. Ann Intern Med 157: ITC1-16.

22. Goi R, Matsuda M, Maekawa H, Ogawa T, Sakata S (1992) Two cases of Hashimoto's thyroiditis with transient hypothyroidism. Intern Med 31: 64-68.

23. Wakim AN, Paljug WR, Jasnosz KM, Alhakim N, Brown AB, et al. (1994) Thyroid hormone receptor messenger ribonucleic acid in human granulosa and ovarian stromal cells. Fertil Steril 62: 531-534.

24. Shu J, Xing L, Zhang L, Fang S, Huang H (2011) Ignored adult primary hypothyroidism presenting chiefly with persistent ovarian cysts: a need for increased awareness. Reprod Biol Endocrinol 9: 119.

25. Doufas AG1, Mastorakos G (2000) The hypothalamic-pituitary-thyroid axis and the female reproductive system. Ann N Y Acad Sci 900: 65-76.

26. Abd-El Fattah (2011) Thyroid gland dysfunction modulates ovarian response to estrogen and androgen receptors in albino rats. The Egyptian Journal of Histology. 34: 182-190.

27. Ghali WM, El-Gohary K, Rafla MF, Doss DN (1989) Effect of Bromocriptine (parlodel L.A.) on the ovary of the adult albino rat. Egypt J Anat 12: 169-184.

28. Nada HF, Lashin SS, El-Hessy H (1994) Effect of experimentally induced hypothyroidism on the ovary of albino rat: A Histological and histochemical study. Egypt J Histol 17: 259 - 268.

29. Gladson M, Govindarojulu P, Srinivasan N (1999) The effect of hypoand hyperthyroidism on uterine and cervical collagens and glycosidases in albino rats. Endocr Res 25: 129-137.

30. Insler V, Lunenfeld B (1991) Pathophysiology of polycystic ovarian disease: new insights. Hum Reprod 6: 1025-1029.

31. Bagavandoss P, England B, Asirvatham A, Bruot BC (1998) Transient induction of polycystic ovary-like syndrome in immature hypothyroid rats. Proc Soc Exp Biol Med 219: 77-84.

32. Ingbar SH (1985) The thyroid gland In: Wilson JD, Foster DW (eds), Textbook of Endocrinology WB Saunders, Philadelphia.

33. Robbins, Cotran (2010) pathologic basis of disease. 2010 Philadelphia Saunders. 
Citation: Treesh SA and Khair NS (2014) Effect of Thyroid Disorders on the Adult Female Albino Rats (Histological and Histochemical Study) . J Cytol Histol 5: 245. doi:10.4172/2157-7099.1000245

Page 9 of 9

34. Dixit VP, Arya M, Lohiya NK (1976) The effect of hypothyroidism on the female genital tract of gerbils (Meriones hurrianae jerdon). Acta Biol Med Ger 35: 205-211.

35. Chan WY, Ng TB (1995) Effect of hypothyroidism induced by propylthiouracil and thiourea on male and female reproductive systems of neonatal mice. J Exp Zool 273: 160-169.

36. Dijkstra G, de Rooij DG, de Jong FH, van den Hurk R (1996) Effect of hypothyroidism on ovarian follicular development, granulosa cell proliferation and peripheral hormone levels in the prepubertal rat. Eur J Endocrinol 134: 649-654.

37. Bhattacharya S, Banerjee J, Jamaluddin M, Banerjee PP, Maitra G (1988) Thyroid hormone binds to human corpus luteum. Experientia 44: 1005-1007.

38. Silver HK (1958) Juvenile hypothyroidism with precocious sexual development. J Clin Endocrinol Metab 18:148 -154.

39. Yamashita Y, Kawamura T, Fujikawa R, Mochizuki H, Okubo M, et al. (2001) Regression of both pituitary and ovarian cysts after administration of thyroid hormone in a case of primary hypothyroidism. Intern Med 40: 751-755.

40. Fares NH (1991) Diethylstilbestrol (DES) induced carbohydrate histochemical changes in murine ovaries. Egypt J Histol 14: 467-481.
41. Rotmensch S, Scommegna A (1989) Spontaneous ovarian hyperstimulation syndrome associated with hypothyroidism. Am J Obstet Gynecol 160: 1220-1222.

42. El-Sherbiny SA, EL-Sayaad HJ, El-Gammal HL, El-Sherbiny EM (2010) Effects of difubenzuron and chlorafluazuron on the histological and histochemical structures of the ovary of albino rats. J Egypt Ger Soc Zool 17: $1-20$.

43. Ganong WF (2001) The ovary In: Barrett K, Brooks H, Boitano S, Barman S. Review of medical physiology (23rd edn), Lange Medical Books/ McGraw Hill.

44. Hamam, AM, Ali UA, El-Tohamy MM (1997) Effect of cadmium and/or zine administration on reproductive and cytogenetic patterns in female rabbits treated with PMSG. J Egypt Ger Soc Zool 22, Histology \& Histochemistry 17-42.

45. Mattar FE, Farid NM, Ragab AF (1981) Histochemical study of atretic ovarian follicles of rat. Egypt J Histol 4: 247 - 252.

46. Riddlesberger MM Jr, Kuhn JP, Munschauer RW (1981) The association of juvenile hypothyroidism and cystic ovaries. Radiology 139: 77-80.

47. Lyon AJ, De Bruyn R, Grant DB (1985) Transient sexual precocity and ovarian cysts. Arch Dis Child 60: 819-822. 